\title{
Obituary: Professor Roger Valentine Short, 31 July 1930-6 August 2021
}

\author{
Jeffrey M. Craig ${ }^{1,2,3}$, John L. Hopper ${ }^{4}$, Nicholas G. Martin ${ }^{5}$, Stephen Tong ${ }^{6,7}$ and Mark P. Umstad ${ }^{6,8}$ \\ ${ }^{1}$ School of Medicine, Faculty of Health, IMPACT - the Institute for Mental and Physical Health and Clinical Translation, Deakin University, Geelong, Victoria, \\ Australia, ${ }^{2}$ Molecular Epidemiology, Murdoch Children's Research Institute, Royal Children's Hospital, Melbourne, Victoria, Australia, ${ }^{3}$ Department of Paediatrics, \\ University of Melbourne, Melbourne, Victoria, Australia, ${ }^{4}$ Centre for Epidemiology and Biostatistics, Melbourne School of Population and Global Health, The \\ University of Melbourne, Melbourne, Victoria, Australia, ${ }^{5}$ Department of Genetics and Computational Biology, QIMR Berghofer Medical Research Institute, \\ Brisbane, Queensland, Australia, ${ }^{6}$ Department of Obstetrics and Gynaecology, University of Melbourne, Parkville, Victoria, Australia, ${ }^{7}$ Mercy Perinatal, Mercy \\ Hospital for Women, Melbourne, Victoria, Australia and ${ }^{8}$ Department of Maternal Fetal Medicine, The Royal Women's Hospital, Melbourne, Victoria, Australia
}

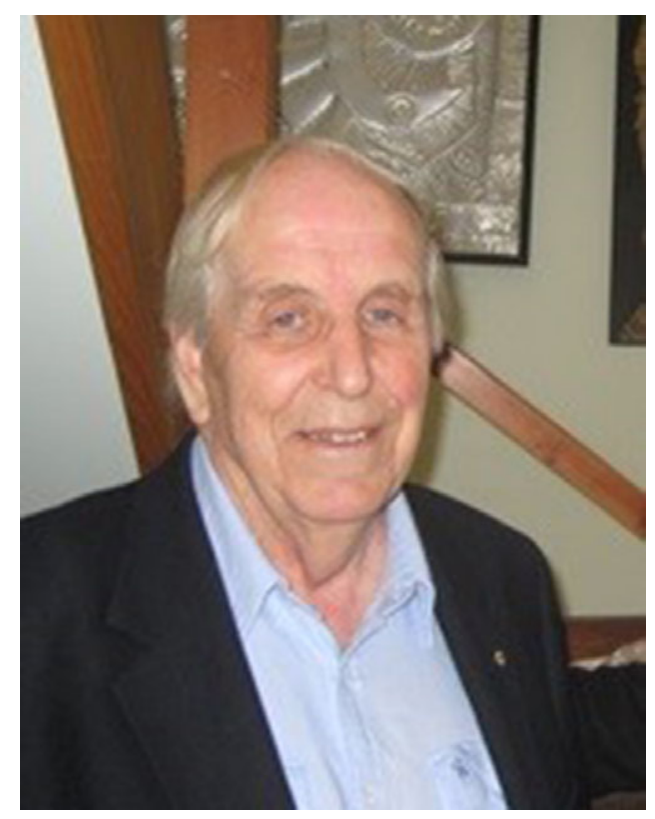

We were saddened to hear that reproductive biologist Professor Roger Short died recently at the age of 91 years. He was survived by his wife and fellow reproductive biologist Professor Marilyn Renfree. Roger, known to many in the twin research community, was a man of great achievements. In this obituary, we will review the more extraordinary aspects of his career, discuss his contributions to twin research and allow twin researchers to reflect on their interactions with Roger.

\section{Biography}

Roger Valentine Short was born in 1930 in Weybridge, a country town in the South of England, not far from where the Magna Carta

Author for correspondence: Jeffrey M. Craig, Email: jeffrey.craig@deakin.edu.au

Cite this article: Craig JM, Hopper JL, Martin NG, Tong S, and Umstad MP. (2021)

Obituary: Professor Roger Valentine Short, 31 July 1930-6 August 2021. Twin Research and Human Genetics 24: 241-243, https://doi.org/10.1017/thg.2021.38 was signed in 1215. He was educated at Bristol, Wisconsin and Cambridge Universities. Over his career as a reproductive biologist, he held many prestigious positions, including Director of the Medical Research Council Unit of Reproductive Biology, Edinburgh 1972-82, and following that, Professor of Reproductive Biology in the Department of Physiology at Monash University in Melbourne. He received many awards, including three medals, and was made a Fellow of four academies. His publications span 65 years and included 18 in Nature, 14 in Lancet and 7 in the BMJ.

Roger had an extraordinary life, some of it summarized in this interview from 2010: https://bit.ly/3xViju5. His father invented the pilot airspeed indicator, which is still used in all aircraft. Roger carried a note from his father every day of his life. Given to him just before he went to university, it contained a quote from Ralph Waldo Emerson that included the words, 'Explore and explore. Be neither criticized nor flattered out of your position of perpetual 
inquiry', a mantra that Roger lived by. Roger's mother, observing that the young Roger was 'fascinated by badgers and other animals', accurately predicted he would be a veterinary researcher. Roger's best friend at school was the boy who would later call himself John le Carré and write best-selling spy novels.

Among his career highlights, Roger's research took him to Uganda, where he studied elephants and crossed the equator every day on his way to and from work.

His work on fertility led to the discovery that in Australian Aboriginal communities, breastfeeding temporarily suppressed ovulation - a natural contraceptive. Contrasted with formula feeding, this had huge implications for population growth.

As a true scientist, Roger questioned everything. He was an enthusiastic advocate of birth control through the contraceptive pill and pointed out that there was no reason why women had to stop taking it for 1 week each month. He went on to show the 'pill' protected women from breast and ovarian cancer. His views on contraception brought him up against the then Archbishop of Melbourne, George Pell, who he simply ignored. $\mathrm{He}$ also clashed with Richard Dawkins on humans' need for a god, after listening to twin researcher Thomas Bouchard at a twins conference talk about the heritability of religiosity. Humans, he argued, have a deep-seated need for spirituality, most likely for purposes of social cohesion.

Roger conceived some extraordinary ideas. For example, from his student's observation on sections of embryonic elephant kidneys, he hypothesized that elephants had an aquatic phase in their recent evolution and this was later borne out by genetic and archaeological studies.

He was inspired by Italian 'adventurer' Giacomo Casanova who encouraged his lovers to use lemon halves as vaginal contraceptives. He confirmed experimentally that lemon juice was an effective contraceptive when used as a douche. He did not stop there, though, and tested his hypothesis that lemon juice would also kill the AIDS virus. Unfortunately, he disproved his own hypothesis but was philosophical about it, saying it hurt to be proven wrong about 'good science'.

Noticing that circumcision reduced the rate of HIV infection in men, Roger hypothesized that application of estrogen cream to uncircumcized foreskin would thicken it and have a similar effect. For the first step, he skipped the need for ethics approval and tried it on himself. A visible thickening convinced him to patent the idea and commence clinical trials. Roger promised to donate the patent rights to South Africa.

Roger's observations of migrating birds led him to wonder how animals timed their seasonal migration. He discovered that this was regulated by the effect of light on the pineal gland, which produces melatonin, the 'hormone of darkness' at night. Taking a conceptional leap forward, Roger hypothesized that taking oral melatonin would counteract the negative effects of jetlag. Again, he tested this on himself, booking a round-the-world flight and regularly monitoring his internal temperatures via a rectal probe. He went on to patent this use of melatonin, which has also been applied in space travel.

Outside academia, Roger had an interest in mitigating climate change. After buying a 400-year-old book on forest laws, he published a paper in Nature suggesting we take a leaf out of King Canute's book and pass laws mandating the planting of new forests. A few years later, on his 80th birthday, his family planted a wood in his honor. A fitting legacy for an extraordinary person.

\section{Contributions to Twin Research}

Roger's interest in twins and higher-order multiples was based on his love for mammalian development, fertility and endocrinology. Roger published at least six papers on multiple births over a period spanning almost 50 years in organisms as diverse as sheep, horses, cows and humans. These three themes came together in a 2016 review on the mechanisms for typical and atypical twinning. In this paper, Roger was well placed to discuss the pros and cons of the controversial fission-fusion model of MZ twinning proposed by Gonzalo Herranz. His deep knowledge of mammalian development was essential for discussions on the contributions of fertility, fecundity and development in generating different types of twins.

\section{Personal Reflections}

Jeff Craig. I was introduced to Roger Short about 2005 when Richard Saffery and I were establishing a twin birth cohort. From that time on, I went to visit him many times to quiz him on twin matters and to listen to his wisdom on higher-order multiples, breastfeeding, fertility and parity. I particularly remember discussions about elephants, the contraceptive and anticancer effects of breastfeeding, macronutrient imbalance in formula milk, and about Marilyn's work on how marsupial mothers change the content of their milk to suit the developmental age of their offspring. We also started hatching a plan for zygosity testing of a set of fetal quintuplets Roger had photographed on a visit to a European anatomy museum. I recall his enthusiasm for all these topics, his depth of knowledge and most of all his kindness in taking the time to see me and others I brought his way. I will miss those discussions.

Mark Umstad. Roger and I first met at a twin conference where we discussed his theory on the death of Eng Bunker who died hours after the death of his conjoined twin, Chang. Roger's presentation of the fascinating lives of the Bunker brothers who prompted the term 'Siamese twins' was immaculately researched, erudite and wonderfully entertaining. His passion for the biology of twinning was infective and prompted my reconsideration of all that I thought true of twinning mechanisms. Our subsequent conversations regarding the reproduction of the nine-banded armadillo - they only reproduce as monozygotic quadruplets or monozygotic octuplets - reinforced the importance of interdisciplinary collaboration for obstetricians researching monozygotic twinning. When I was struggling to understand chimeric twinning, I turned to Roger, who explained the mechanism by referring to a paper he had written more than 40 years earlier for the Royal Society on bovine freemartins. Subsequently, our team critically reviewed all aspects of typical and atypical twinning under Roger's expert guidance for our 2016 paper on the topic. His inquisitive mind, passion for discovery, generosity of spirit and extraordinary intellect will be sorely missed.

John Hopper. Roger was great educator, and I fondly remember having the pleasure of sitting in on his classes to medical students about all things twinning. Roger also made important contributions to Twins Research Australia (then known as the Australian Twin Registry) as a member of the Executive committee and especially in running a research tent at the inaugural Twins' Picnic we held at Government House, Melbourne, in March 2001. Roger had picked up on a comment Sam Berkovic made to me suggesting that, from his observations, the zygosity of twin pairs might be easily determined by looking at their ears. Always the experimentalist Roger and Stephen Tong took the opportunity 
of having hundreds of twin pairs in attendance to take aural photographs and collect a cheek swab to test Sam's hypothesis. It was a hit with the twins and inspired more zygosity-related research at another Twins' Picnic a decade later, led by Jeff Craig. Roger was a passionate advocate for twins being zygosity tested at birth. He always had a smile and a glint in his eye when you met him, and something new that excited him. What fun.

Stephen Tong. Roger was a master orator. For instance, he developed a deep passion to warn all of the dangers of unchecked human population growth. I can vouch for the fact that his lectures on the topic to science and medical students were phenomenal. By the end of each lecture series, he would have predictably touched students so much that legions would flock to him, jostling to join his crusade, to make a difference. I was also privileged to witness him deliver a plenary presentation at an Andrology conference in Belgium in the late $90 \mathrm{~s}$. He began by announcing he had abandoned his slides and then proceeded to present 'off-the-cuff. The oration was so utterly moving that during the periods of silence punctuating precisely chiselled sentences it would have been absolutely possible to 'hear a pin drop'.

Nick Martin. Not living in Melbourne, I only knew Roger through our encounters at International Society of Twin Studies (ISTS) conferences every 2 or 3 years where he unfailingly made, in his cultured, resonant voice, incisive and erudite contributions after almost every paper. I was particular flattered that he took a great interest in my own work on the genetics of DZ twinning and made many constructive suggestions. I am only sorry he died before I had a chance to show him our latest exciting findings on a strong methylation signature in human MZ twinning and (see Mark Umstad above) plotting how to extend this to ninebanded armadillos! ISTS has lost a great scholar, friend and supporter. 